\title{
Updating the distribution of the exotic agave weevil Scyphophorus acupunctatus Gyllenhal, 1838 (Coleoptera: Curculionidae) in peninsular Spain
}

Adrián Martín-Taboada, Antonio Román Muñoz \& Francisco Díaz-Ruiz

Biogeography, Diversity, and Conservation Research Team, Dept. Biología Animal, Facultad de Ciencias, Universidad de Málaga, E-29071, Málaga, Spain.

Correspondence
AR. Muñoz
E-mail: roman@uma.es
Received: 21 January 2019
Accepted: 10 April 2019
Published on-line: 31 May 2019

\section{Correspondence}

AR. Muñoz

E-mail: roman@uma.es

Received: 21 January 2019

Published on-line: 31 May 2019

\section{Resumen}

Actualizando la distribución del exótico picudo negro del ágave Scyphophorus acupunctatus Gyllenhal, 1838 (Coleoptera: Curculionidae) en España peninsular

Las invasiones biológicas se consideran en la actualidad como uno de los principales factores que condicionan la pérdida de biodiversidad en el planeta. En las últimas décadas, se ha incrementado el número de especies exóticas/invasoras detectadas en España. Este es el caso del picudo negro (Scyphophorus acupunctatus), un coleóptero (familia Curculionidae) originario de América, especializado en el consumo de plantas de las familias Agavaceae y Dracaenaceae. Detectado por primera vez en España en 2007, en Barcelona, ha sufrido una amplia expansión por todo el arco Mediterráneo. A partir de la recopilación de citas obtenidas de diferentes bases de datos, así como de otras obtenidas por los autores, se presenta una actualización de la distribución de esta especie para la España peninsular, discutiendo su potencial invasor.

Palabras clave: Especies exóticas; Insectos; Invasiones biológicas; Mediterráneo; Plaga.

\begin{abstract}
Biological invasions are considered one of the main factors conditioning the loss of biodiversity on the planet. During the last decades an increase in the number of exotic/invasive species has been detected in Spain. This is the case of the agave weevil (Scyphophorus acupunctatus), an American coleoptera (Curculionidae family) specialized in plants of the families Agavaceae and Dracaenaceae. It was detected for the first time in Spain in Barcelona in 2007. Since then it has suffered a wide expansion throughout the Iberian Mediterranean arc. From the compilation of citations obtained from different databases, as well as others obtained by the authors, an update of the distribution of this species is presented for peninsular Spain. We also discussed its invasive potential.
\end{abstract}

Key words: Alien species; Biological invasion; Insects; Mediterranean; Pest. 


\section{Introduction}

Human actions are producing environmental alterations and, as a result, many populations are exposed to novel perturbations. Exotic species are, by definition, taxa that have been introduced outside its natural range, through human intervention, either intentionally or accidentally (IUCN 2000). It is widely recognized that invasive alien species pose a serious threat to biodiversity (Pimentel 2002), and also that insects have received less attention concerning their effects on the environment compared to other groups as vertebrates (e.g. Real et al. 2008, Preston et al. 2012), or plants (e.g. McCary et al. 2016, Nelson et al. 2017), even being an important part of the alien fauna worldwide (Kenis et al. 2009).

The agave weevil Scyphophorus acupunctatus is native to Mexico (Vaurie 1971), and a major pest of wild and cultivated Agavaceae and Dracaenaceae species worldwide (Azuara-Domínguez 2013). The international importation of ornamental Agave L. plants has enabled this species to establish in many parts of the world, mainly in Central America and the Caribbean, Africa, Asia, South America (Servín et al. 2006), and more recently in Western Europe (Colombo 2000, RibaFlinch \& Alonso-Zarazaga 2007). This weevil is about $12 \mathrm{~mm}$ in length, has cryptic habits, and all of its life stages take place inside host tissues (Terán-Vargas et al. 2012), making its detection and control difficult. Although it has devastated populations of Agave crops (Solís-Aguilar et al. 2001, Camino et al. 2002), around the Mediterranean Basin the species damages are mostly focused on ornamental species, such as the genera Agave, Beaucarnea Lem., Dasylirion Zucc., Dracaena Vand. ex L. and Yucca L., which also entail important economic costs (Riba-Flinch \& AlonsoZarazaga 2007). Several methods have been tested and implemented for the agave weevil pest management in its native distribution range (Rodríguez-Rebollar et al. 2012, Terán-Vargas et al. 2012). However, to ensure the effectiveness of any management strategy in areas of new colonization it is crucial to have a good knowledge of its current distribution, as well as information related to the spatial evolution of its populations.

The presence of this species in the Iberian Peninsula is relatively recent, being detected for the first time in 2007 in a small village close to Barcelona city (NE Spain) (Riba-Flinch \&
Alonso-Zarazaga, 2007). From this first record until 2013 the presence of the agave weevil was confirmed in $2510 \times 10 \mathrm{~km}$ UTM grids located in three isolated areas in Eastern Spain: Barcelona (Catalonia, 4 grids), Alicante (Valencia Community, 15 grids) and Murcia Community (6 grids) (Molina 2013). Since the revision of Molina (2013), the distribution of the agave weevil in peninsular Spain has not been updated. In this respect, the main aim of this study is to update its distribution in peninsular Spain to get a clearer view of its potential for invasiveness.

\section{Materials and methods}

Information on the evolution of the distribution of invasive alien species is difficult to obtain, especially during the initial stages of the invasion, and even more for cryptic species like the agave weevil (Terán-Vargas et al. 2012). In this context, we have checked different sources of information to obtain new presence data of the agave weevil in peninsular Spain. First, we reviewed the available scientific literature using different search engines (e.g. ISI Web of Science, Scopus and Google Scholar). We did it using these combinations of keywords: 'agave weevil' or 'Scyphophorus acupunctatus' and 'presence' or 'distribution' and 'Iberian Peninsula' or 'Spain'. In addition, we performed several searches using Google and the same keywords above mentioned in Spanish, in order to identify new records of the species in local/regional media and webs platforms. We also requested information to the Environmental Agencies of the regional governments around the Spanish Mediterranean basin: Andalusia, Catalonia, Murcia and Valencian Community, areas with a high probability of the presence of the agave weevil, according to the available information (Molina 2013). We also reviewed records from the biodiversity database Biodiversidad Virtual (https: //www.biodiversidadvirtual.org/), a web platform which receives data from nature photographers, who upload pictures of a wide range of taxa, including the geographical location where the pictures were taken. All uploaded pictures are checked by experts in each taxon to confirm the species identification. Therefore, we only considered those presences that were previously confirmed. Finally, we collected new records obtained from the fieldwork developed in different research projects. All collected data were included 
in a georeferenced database using a Geographic Information System (QGIS 1.8.0; QGIS Development Team 2013) to associate each record to its corresponding 10x10 km UTM grid.

\section{Results}

We have confirmed the presence of the agave weevil in 65 new 10x10 km UTM squares (hereafter grids) (Table 1). Overall, the presence of the agave weevil is currently confirmed in 90 grids, which is an increase of 3.6x in its known distribution range compared to the distribution map published by Molina (2013) (see figure 1 and table 1). Most of the new presences were obtained from the Biodiversidad Virtual database ( $\mathrm{n}=37$ grids). With respect to the request of information to the environmental agencies we only got response from the Catalonia and Valencia Regional Governments ( 0 and 21 new grids, respectively). We only found one scientific paper with a new presence (López-
Pérez 2014), and another one that came from a regional digital newspaper (https://andaluciainformacion.es/). The rest of the new grids were obtained from our field work $(n=5)$. According to these new data, the distribution range of the isolated populations of Barcelona, Alicante and Murcia have increased $1.75 \mathrm{x}, 3.93 \mathrm{x}$ and $1.17 \mathrm{x}$, respectively, being at present almost joined (Figure 1). We have detected new presences in Andalusia, where the species has been mostly detected in the Mediterranean coast (17 new grids), but also in the Atlantic coast, where is already occupying at least 2 grids.

\section{Discussion}

The results of our review significantly improve and update the knowledge about the distribution of the agave weevil in peninsular Spain. The new map quadruples the previously known distribution described by Molina (2013). This may seem un-

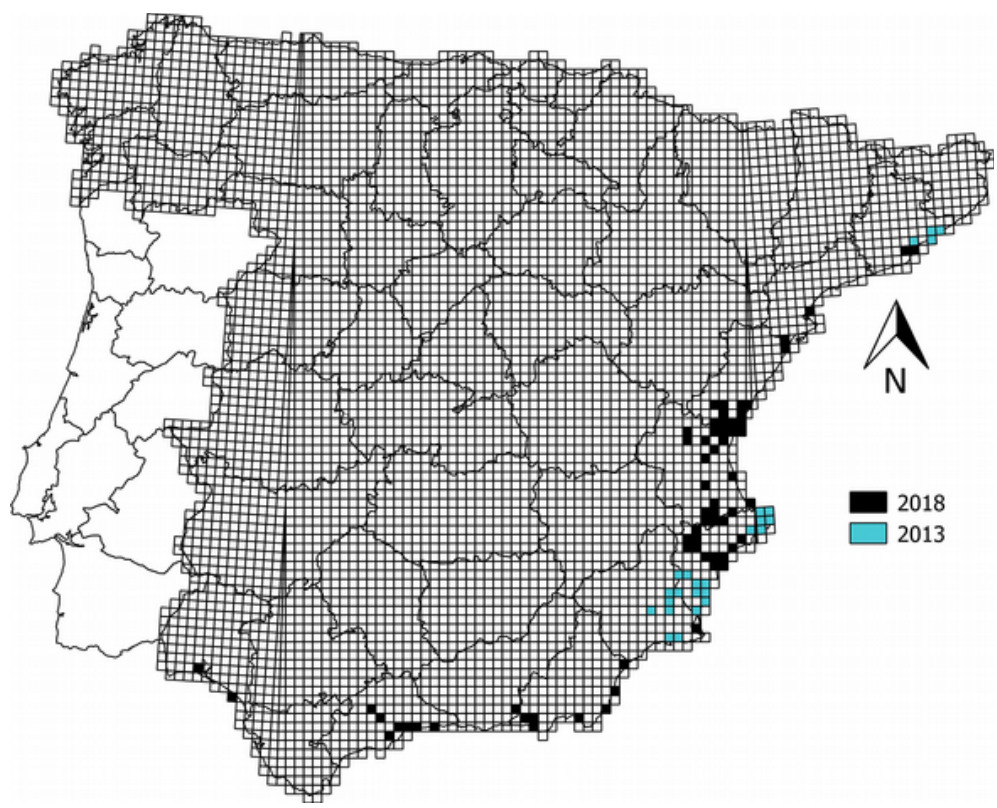

Figura 1. Mapa actualizado de la distribución de Scyphophorus acupunctatus en España peninsular. En azul, la distribución conocida hasta el año 2013 (Molina 2013) y en negro las nuevas presencias obtenidas en este trabajo.

Figure 1. Updated map of the distribution of Scyphophorus acupunctatus in peninsular Spain. In blue, the known distribution until the year 2013 and in black the new records obtained in this study.

\begin{tabular}{|c|c|c|c|c|c|}
\cline { 2 - 6 } \multicolumn{1}{c|}{} & $\begin{array}{c}\text { Cataluña/ } \\
\text { Catalonia }\end{array}$ & $\begin{array}{c}\text { C. Valenciana/ } \\
\text { Valencian Community }\end{array}$ & Murcia & $\begin{array}{c}\text { Andalucía/ } \\
\text { Andalusia }\end{array}$ & Total \\
\hline $\mathbf{2 0 1 3}$ & 4 & 15 & 6 & - & 25 \\
\hline $\mathbf{2 0 1 8}$ & 3 & 44 & 1 & 17 & 65 \\
\hline TOTAL & 7 & 59 & 7 & 17 & 90 \\
\hline
\end{tabular}

Tabla 1. Datos de presencia de Scyphophorus acupunctatus en España peninsular, comparación entre datos del año 2013 (Molina 2013 ) y 2018 (este estudio). Se muestra el número de cuadrículas UTM 10x10 km.

Table 1. Presence data of Scyphophorus acupunctatus in peninsular Spain, comparison between the data from the year 2013 and 2018 (present study). The number of 10x10 km UTM grid squares is shown. 
usual if we take into account that it was considered a species with a low dispersal capacity (Setliff \& Anderson 2011). Although the observed spread could have been facilitated by the trade of ornamental plants infected by the weevil, as indicated by Molina (2013), it has recently been described the ability of the species to fly, so it could have a greater potential for natural dispersion than previously thought (Charro et al. 2017). In any case, and regardless of its dispersive capacity, our map surely includes false absences because the species may have gone easily unnoticed in already occupied areas. On the one hand, its small size and cryptic habits make it difficult to detect (Terán-Vargas et al. 2012), especially at the early stages of invasion. On the other hand, the species is not yet well known by the citizens, unlike the red weevil (Rhynchophorus ferrugineus L.), a well-known invasive species pest of palm trees worldwide (Faleiro 2006). These facts make difficult to get reports from citizens, a good source of information to monitor wildlife and invasive species (Chandler et al. 2017). Furthermore, the species has not been included yet in the Spanish catalogue of invasive alien species (Real Decreto $630 / 2013$, August $2^{\text {th }}$ ), so no monitoring efforts have been made by the environmental administration at the national or local levels.

The updated distribution for this species in Spain occurs mostly along the Mediterranean basin, overlapping with the distribution of its primary feed, the maguey Agave americana (Sanz et al. 2004), another exotic invasive species in Spain. Thus, we could expect that the distribution of the agave weevil could be restricted to the distribution range of the maguey, so the presence of the agave weevil could be considered as a lesser evil. However, the agave weevil also attacks plants of high economic value, as the ornamental Yucca spp. (Pott 1975), or plants used in the food and cosmetic industries, like Aloe spp. (Kelly \& Olsen 2006). This is another reason to consider that the distribution in peninsular Spain could be underestimated because it would not be limited by the presence of the maguey.

Our study provides an updated distribution of the invasive agave weevil in peninsular Spain, although the current range occupied by species is surely larger than shown in this study. On this sense, our results reveal some potential gaps of knowledge about its distribution in Spain, and help to identify new sampling areas. In this respect, a follow-up program would be necessary to monitor the population spread. This would provide a better knowledge of its distribution and a better understanding of the factors determining it, in order to apply appropriate management measures for this new invasive species. This would be essential to manage populations and promote the early reaction against undesired settlements.

\section{Acknowledgements}

F. Díaz-Ruiz was supported by a "Juan de la Cierva" research contract (Ministerio de Ciencia e Innovación, Funder Id: 10.13039/501100004837, FJCI-2015-24949) from the Spanish Ministry of Economy, Industry and Competitiveness. Two anonymous reviewers provided helpful comments on a previous version of the manuscript.

\section{References}

Azuara-Domínguez A, Cibrián-Tovar J, Terán-Vargas AP, Segura-León, OL \& Cibrián-Jaramillo A. 2013. Factors in the response of Agave Weevil, Scyphophorus acupunctatus (Coleoptera: Curculionidae), to the major compound in its Aggregation Pheromone. Southwestern Entomologist 38: 209-220.

Camino LM, Figueroa VC, Aldana L. \& Valdés ME. 2002. Scyphophorus acupunctatus Gyellenhal (Coleoptera: Curculionidae), attacking Polianthes tuberosa (Liliales: Agavacea) in Morelos, México. Florida Entomologist 85: 392-393.

Chandler M, See L, Copas K, Bonde AMZ, López BC, Danielsen F, Legind JK, Masinde S, Miller-Rushing AJ, Newman G, Rosemartin A \& Turak E. 2017. Contribution of citizen science towards international biodiversity monitoring. Biological Conservation 213: 280-294.

Charro A, Gallego D, Lencina JL \& Gómez de Dios, MA. 2017. El picudo negro, Scyphophorus acupunctatus Gyllenhal, 1838, en Andalucía. XXXIII Jornadas de la Asociación española de Entomología. Almería, 15-18/11/2017.

Colombo M. 2000. Scyphophorus acupunctatus Gyllenhal (Coleoptera: Curculionidae): prima segnalazione per I'Italia. Bolletino di Zoologia Agraria e di Bachicoltura, Serie II 32: 165-170.

Faleiro J. 2006. A review of the issues and management of the red palm weevil Rhynchophorus ferrugineus (Coleoptera: Rhynchophoridae) in coconut and date palm during the last one hundred. International Journal of Tropical Insect Science 26: 135-154.

IUCN. 2000. Guidelines for the Prevention of Biodiversity Loss Caused by Alien Invasive Species. International Union for the Conservation of Nature. Gland, Switzerland: IUCN.

Kelly J \& Olsen M. 2006. Problems and Pests of Agave, Aloe, Cactus and Yucca. Arizona Cooperative Exten- 
sion, AZ 1399: 12.

Kenis M, Auger-Rozenberg MA, Roques A, Timms L, Péré C, Cock MJW, Settele J, Augustin S \& LopezVaamonde C. 2009. Ecological effects of invasive alien insects. Biological Invasions 11: 21-45.

López-Pérez JJ. 2014. Contribución al conocimiento de los coleópteros (Coleoptera) de Huelva III - Los Puntales, Paraje Natural de Marismas del Odiel (S.O. de Andalucía, España). Arquivos Entomolóxicos 12: 3752.

McCary MA, Mores R, Farfan M \& Wise DH. 2016. Invasive plants have different effects on trophic structure of green and brown food webs in terrestrial ecosystems: a meta-analysis. Ecology Letters 19: 328-335.

Molina D. 2013. Contribución al conocimiento de la distribución actual de la especie invasora Scyphophorus acupunctatus Gyllenhal, 1838 (Coleoptera: Dryophthoridae) en la Península Ibérica. Revista gaditana de Entomología 4: 11-16.

Nelson SB, Coon JJ, Duchardt CJ, Fischer JD, Halsey SJ, Kranz AJ, Parker CM, Schneider SC, Swartz TM \& Miller JR. 2017. Patterns and mechanisms of invasive plant impacts on North American birds: a systematic review. Biological Invasions 19: 15471563.

Pimentel D. 2002. Biological invasions. Economic and environmental costs of alien plants, animal and microbe species. Boca Raton, Costa Rica: CRC Press.

Preston DL, Henderson JS \& Johnson PTJ. 2012. Community ecology of invasions: direct and indirect effects of multiple invasive species on aquatic communities. Ecology 93: 1254-1261.

Pott JN. 1975. A yucca borer Scyphophorus acupunctatus in Florida. Florida State Horticultural Society 88: 414-416.

QGIS Development Team. 2013. QGIS Geographic Information System. Open Source Geospatial Foundation Project. Available on http://qgis.osgeo. org
Real R, Márquez AL, Estrada A, Muñoz AR \& Vargas JM. 2008. Modelling chorotypes of invasive vertebrates in mainland Spain. Diversity and Distributions 14: 364-373.

Riba-Flinch JM \& Alonso-Zarazaga MA. 2007. El picudo negro de la pita o agave, o max del henequén, Scyphophorus acupunctatus Gyllenhal, 1838 (Coleoptera: Dryophthoridae): primera cita para la Península Ibérica. Boletín de la Sociedad Entomológica Aragonesa 41: 419-422.

Rodríguez-Rebollar H, Rojas JC, González-Hernández $H$, Ortega-Arenas LD, Equihua-Martínez A, Del Real-Laborde JI \& López-Collado J. 2012. Evaluación de un cebo feromonal para la captura del picudo del agave (Coleoptera: Curculionida). Acta Zoológica Mexicana 28(1): 73-85.

Sanz M, Dana ED \& Sobrino E (eds.). 2004. Atlas de las Plantas Alóctonas Invasoras en España. Madrid: Dirección General para la Biodiversidad.

Servín R, Tejas A, Montoya MA \& Robert ML. 2006. Scyphophorus acupunctatus Gyllenhal (Coleoptera: Curculionidae) como potencial insecto-plaga de Yucca valida Brandegee en Baja California Sur, México. Folia Entomologica Mexicana 45: 1-7.

Setliff GP \& Anderson JA. 2011. First Record of the Agave Snout Weevil, Scyphophorus acupunctatus Gyllenhal (Coleoptera: Curculionidae: Dryophthorinae), in Puerto Rico. Insecta Mundi, 152: 1-3.

Solís-Aguilar JF, Hernández $\mathrm{H}$, Leyva JL, Equihua A, Flores FJ \& Martínez A. 2001. Scyphophorus acupunctatus Gyllenhal, an agave tequilero pest in Jalisco, México. Agrociencia 35: 663-670.

Terán-Vargas A, Azuara-Domínguez A, Vega-Aquino $P$ Zambrano-Gutiérrez J \& Blanco C. 2012. Biological effectivity of insecticides to control the agave weevil, Scyphophorus acupunctatus Gyllenhal (Coleoptera: Curculionidae), in Mexico. Southwestern Entomologist 37: 1-7.

Vaurie P. 1971. Review of Scyphophorus (Curculionidae: Rhynchophorinae). The Coleopterists Bulletin 25: 1-8. 